\title{
TNK2 wt Allele
}

National Cancer Institute

\section{Source}

National Cancer Institute. TNK2 wt Allele. NCI Thesaurus. Code C51063.

Human TNK1 wild-type allele is located within 3q29 and is approximately $46 \mathrm{~kb}$ in length.

This allele, which encodes activated CDC42 kinase 1 protein, plays a role in signal transduction. 